\section{Healthy life expectancy in Brazil: applying the Sullivan method}

\author{
Expectativa de vida saudável no Brasil: \\ uma aplicação do método de Sullivan
}

Dalia Elena Romero 1

Iúri da Costa Leite 2

Célia Landmann Szwarcwald 1
1 Centro de Informação Científica e Tecnológica, Fundação Oswaldo Cruz, Rio de Janeiro, Brasil.

2 Escola Nacional de Saúde Pública Sergio Arouca Fundação Oswaldo Cruz, Rio de Janeiro, Brasil.

Correspondence D. E. Romero Departamento de Informações em Saúde, Centro de Informação Científica e Tecnológica, Fundação Oswaldo Cruz. Av. Brasil 4365,

Rio de Janeiro, $R J$ 21045-900, Brasil. dalia@cict.fiocruz.br

\section{Abstract}

The objective of this study is to present the method proposed by Sullivan and to estimate the healthy life expectancy using different measures of state of health, based on information from the World Health Survey carried out in Brazil in 2003. By combining information on mortality and morbidity into a unique indicator, simple to calculate and easy to interpret, the Sullivan method is currently the one most commonly used for estimating healthy life expectancy. The results show higher number of healthy years lost if there is a long-term disease or disability that limits daily activities, regardless of the difficulty in performing such activities or the severity of the functional limitations. The two measures of healthy life expectancy adjusted by the severity of functional limitation show results very similar to estimates based on the perception of state of health, especially in advanced age. It was also observed, for all measures used, that the proportion of healthy years lost increases significantly with age and that, although females have higher life expectancy than males, they live proportionally less years in good health.

Chronic Diseases; Health Status; Life Expectancy; Years of Lost Life

\section{Introduction}

Classically, mortality indicators have been utilized to evaluate the general state of health of a population. These indicators highlight life expectancy, which, because it is not influenced by a population's age structure, has been used to compare the health state between populations and also to monitor the impact of different interventions in the health area 1.

The increase in life expectancy is not only a characteristic of developed countries, having also shown significant increased in developing countries, especially in the second half of the $20^{\text {th }}$ century 2 . According to estimates by the United Nations 3 , between 1950 and 2000, Latin America witnessed an increase of approximately 14 years in life expectancy from birth, rising from 51.6 years to 65.4 years for both sexes. A similar gain is observed in Brazil where the life expectancy rose from 51 years to 69.4 years during the same timeframe. Demographic projections foresee the continuation of this process, estimating a life expectancy in Brazil around 77.4 years in 20303.

The decline in mortality at young ages and the increase in longevity, combined with the decline of fecundity and the accentuated increase of degenerative chronic diseases, caused a rapid process of demographic and epidemiologic transition, imposing a new public health agenda in the face of the complexity of the new morbidity pattern 4 . 
Recent studies on longevity and health concluded that the positive tendencies of prolonged life were not accompanied by similar trends in the extension of healthy life; in other words, a long life does not necessarily mean a healthy life 5,6,7. On the contrary, with increased life expectancy, the proportion of years of life with degenerative chronic diseases, disabilities and socioeconomic disadvantages also increased 8,9. Advancement in the technologies for saving lives and providing more efficient medical care resulted in the paradoxical increase in the prevalence of chronic diseases, as Gruenberg named 10, "the failure of success".

It is thus arguable that mortality measurements alone are insufficient to adequately evaluate state of health, quality of life in a population, or the comparative impact of medical interventions. In the last four decades, great effort has been spent to develop synthetic health measures that consider, besides the effect of mortality, morbidity, limitations and disabilities, as well as concepts relative to the well-being and the quality of life of a population 2,11,12. The first method to combine morbidity and mortality information was proposed by Sanders 13 and later developed by Sullivan 14 .

The key measures of the Sullivan method have been called healthy life expectancy, active life expectancy or life expectancy free of disability, depending on the selected information to measure the state of health. Due to its simplicity, the Sullivan method has been used to estimate healthy life expectancy in various countries $11,15,16$, especially the developed ones, as well as for monitoring health changes and differences in the European countries. In Brazil it was employed to calculate healthy life expectancy using the SABE (Saúde, Bem-estare Envelhecimento; Health, Well-Being, and Aging) research database, which is restricted to the elderly in the city of São Paulo 17.

The objective of this study is to introduce Sullivan's technique and estimate healthy life expectancy in Brazil using different ways of measuring state of health, based on information from the Pesquisa Mundial de Saúde (World Health Survey - WHS), carried out in 2003 on a national scale.

\section{Methods and materials}

\section{The Sullivan method}

The information necessary for applying the Sullivan method are: (1) population and deaths or specific mortality rates that permit the con- struction of a life table; (2) prevalence of health states according to age.

In the present study, the morbidity information used in applying the Sullivan method comes from the WHS that was carried out in Brazil in 2003. This research is part of a larger project from the World Health Organization (WHO), in which many other member countries where included.

The WHS sample was comprised of 5,000 Brazilians over the age of 18 , selected, probabilistically, in 250 census sectors, in 188 municipalities located in the 25 states of the federation. The sampled population corresponded to the set of private residences in Brazil except for the ones located in rural areas of northern region, in the states of Acre and Roraima, and in special census sectors (military bases, lodgings, encampments, boats, penitentiaries, asylums, orphanages, convents, or hospitals) 18.

Specific mortality rates by age and sex were provided by the Departamento de População e Indicadores Sociais, Instituto Brasileiro de Geografia e Estatística (DEPIS, Department of Population and Social Indicators; IBGE, Brazilian Institute of Geography and Statistics).

The healthy life expectancy or expectancy of a life free of disability, proposed by Sullivan, is calculated using an adaptation of the traditional life table. The expectancy of healthy life thus reflects the state of health of a determined population adjusted by the level of mortality and, as in a life table, it is not affected by the age structure of a population. In the present study, healthy life expectancies were estimated according to sex, since health states vary considerably between genders, especially at more advanced ages 19,20,21.

The healthy life expectancy $\left(e_{x}^{\prime}\right)$ is calculated in the following manner:

$$
e_{x}^{\prime}=\frac{1}{l_{x}} \sum_{x}^{w}\left(1-{ }_{n} \pi_{x}\right)_{n} L_{x} \quad \text { (1), where: }
$$

$l_{x}$ is the number of survivors at the exact age $\mathrm{x}$; $n \pi_{x}$ represents the prevalence of a determined state of health among individuals with ages in the interval $(\mathrm{x}, \mathrm{x}+\mathrm{n}) ;{ }_{n} L_{x}$ is the total number of years lived by a cohort in the age group $(\mathrm{x}, \mathrm{x}+$ $\mathrm{n}) ; w$ represents the largest age category.

According to what can be observed, the model employs two independent measures of health. The first refers to morbidity, $\left(1-n \pi_{x}\right)$, which is the specific rate by age of being healthy; and ${ }_{n} L_{x}$ which is the mortality component. The method thus consists of removing from the total time lived by a cohort the proportion lived without good health. 


\section{Indicators of healthy life}

Since the Sullivan method depends on how one measures healthiness, the present study employs four distinct estimates of healthy life expectancy covering several dimensions of morbidity: self-rated health, presence of long-term disease or disability, and functional limitations.

The first method refers to the individual self-rated health obtained with the following question: "In general, how would you rate your health today?". There are five possible answers (very good, good, moderate, bad, very bad), which have been dichotomized such that the answers "very bad" and "bad" constitute the category "poor self-rated health", and the other answers compose "good self-rated health". In this case, the specific rate by age of being healthy was established by the proportion of individuals with a good perception of health state in each quinquennial age group.

The second measure is based on the presence of a long-term disease or disability that limits the one's daily activities, and is ascertained with the following two questions: "do you have any long-term illness or disability?" and "does the illness or disability limit in any way your daily activities?". For this estimate, the state of having a long-term disease or disability that limits daily activities was used to identify an unhealthy life and the specific rate by age was established by the proportion of individuals with a long-term disease or disability in each age group.

Differently from the first two estimates, where being healthy is defined by a dichotomous variable, the third estimate takes into consideration the continuum of the severity of functional limitations. For such, this study considered the approach proposed by the WHO in the International Classification of Functionality, Disability and Health (ICF) 22, in which the limitations of activities and functionality are not only viewed as a consequence of illnesses but principally as important components in an individual's health. So as to obtain a measurement of the severity of functional limitations on a continuous scale, the present study first made use of a factorial analysis of principal components, which was applied to the five levels of difficulty (none, mild, moderate, severe, extreme) in performing daily activities (professional and personal, self-care, locomotion, learning, and application of knowledge) and limitation and deficiencies of the body's functions and structure (sensory and mental functions), as shown in Table 1. Using the scores in the first principal component, a scale from 0 to 1 was thus constructed so that 1 is equivalent to the greatest degree of severity and 0 corresponds to a healthy life (without limitations). In this manner, the specific rate by age of being healthy is given by the complement of the

Indicators, defined by the International Classification of Deficiencies, Functionality, and Disabilities in Health 22 , employed to estimate the second the measure of healthy life.

\begin{tabular}{|c|c|c|c|}
\hline Components & Domains (chapters) & Categories & Questions from WHS \\
\hline \multirow[t]{5}{*}{ Activity limitations } & 6. Domestic life & Doing housework (d640) & $\begin{array}{l}\text { q2001 - degree of hardship } \\
\text { with domestic tasks or activities? }\end{array}$ \\
\hline & 4. Mobility & Walking short distances (d4500) & $\begin{array}{l}\text { q2010 - degree of hardship } \\
\text { with locomotion? }\end{array}$ \\
\hline & 5. Self-care & Dressing (d540) & $\begin{array}{l}\text { q2020 - degree of hardship in caring } \\
\text { for oneself, such as washing } \\
\text { and dressing? }\end{array}$ \\
\hline & & & $\begin{array}{l}\text { q2021 - degree of hardship in caring } \\
\text { for oneself, such as maintaining } \\
\text { a proper and clean appearance? }\end{array}$ \\
\hline & $\begin{array}{l}\text { 1. Learning and applying } \\
\text { knowledge }\end{array}$ & Acquire skills, unspecific (d1559) & $\begin{array}{l}\text { q2051 - degree of hardship } \\
\text { in learning a new task? }\end{array}$ \\
\hline \multirow[t]{2}{*}{$\begin{array}{l}\text { Limitations and deficiencies } \\
\text { in function and body structure }\end{array}$} & $\begin{array}{l}\text { 2. Sensory functions } \\
\text { and pain }\end{array}$ & Sensation of pain (b280) & $\begin{array}{l}\text { q2030 - degree of pain felt in body? } \\
\text { q2031 - degree of physical illness felt? }\end{array}$ \\
\hline & 1. Mental functions & Attention functions (b140) & $\begin{array}{l}\text { q2050 - degree of hardship } \\
\text { in concentrating or remembering things? }\end{array}$ \\
\hline
\end{tabular}


arithmetic average of the scale's values by age group.

The final method used for measuring state of health is a proposed extension of the Sullivan method, which allows more than one healthy life-defining event to be used simultaneously. In addition, a weight is attributed to each event, establishing the degree of its severity. To illustrate the method, three events were considered: (1) does not have long-term disease or disability; (2) has a long-term disease or disability that does not limit daily activities; and (3) has a long-term disease or disability that limits daily activities. The weights which characterize the degree of severity in each situation were calculated by age group, as the arithmetic mean of the scores of functional limitations in a scale varying from 0 to 1 , obtained from factor analysis.

\section{Applying the method}

In this study, the life table used to illustrate the Sullivan method's calculation has been summarized in quinquennial age groups, beginning at twenty years of age, since the informa- tion from the WHS refers to individuals 18 years or older. Use of the summarized life table is recommended in studies of this type, since prevalence rates of age-specific health events, obtained through research samples, are too small to be used with simple ages 21 .

Table 2 shows the application of the Sullivan method, taking into consideration the proportion of individuals in each quinquennial age group with a self-rated health that is not poor (very good, good, moderate) as the specific rate by age of being healthy. The first column represents the age group 's lower limit, in which the amplitude always equals five, except for the last group in which the interval is right open. The five following columns show the functions of a summarized mortality table, necessary for the calculation of life expectancy.

In the second column are the specific rates of mortality $\left({ }_{5} M_{x}\right)$. Based on the specific rate of mortality, the probability of an individual with exact age $x$ dieing before completing $x+5\left({ }_{5} q_{x}\right)$ years is calculated. Since the table begins at twenty years of age, it was assumed that deaths occur uniformly within the quinquennial age groups, so that the probabilities are calculated with the following expression

Table 2

Healthy life expectancy, for both sexes, based on self-evaluation of poor health. World Health Survey, Brazil, 2003.

\begin{tabular}{|c|c|c|c|c|c|c|c|c|c|c|c|c|}
\hline \multirow{2}{*}{$\begin{array}{l}\text { Age } \\
1\end{array}$} & \multirow[b]{2}{*}{$\begin{array}{c}2 \\
\text { Mortality } \\
\text { rates }\end{array}$} & \multirow[b]{2}{*}{$\begin{array}{c}3 \\
\text { Probability } \\
\text { of death }\end{array}$} & \multicolumn{3}{|c|}{ Traditional life table } & \multirow{2}{*}{$\begin{array}{c}7 \\
\text { Life } \\
\text { expectancy }\end{array}$} & \multirow{2}{*}{$\begin{array}{c}\text { Poor health } \\
8 \\
\text { Prevalence } \\
(\%)\end{array}$} & \multicolumn{2}{|c|}{ People-years } & \multicolumn{3}{|c|}{ Life expectancy } \\
\hline & & & $\begin{array}{c}4 \\
\text { Survivors }\end{array}$ & $\begin{array}{c}5 \\
\text { Years } \\
\text { lived } \\
\text { between } \\
\text { ages } x \\
x+n\end{array}$ & $\begin{array}{c}6 \\
\text { Years } \\
\text { lived, } \\
\text { starting } \\
\text { at age } x\end{array}$ & & & $\begin{array}{c}9 \\
\text { With } \\
\text { good } \\
\text { self-rated } \\
\text { health } \\
\text { between } \\
\text { the ages } \\
(x ; x+n)\end{array}$ & $\begin{array}{l}10 \\
\text { With } \\
\text { good } \\
\text { self-rated } \\
\text { health } \\
\text { starting } \\
\text { at age } x\end{array}$ & $\begin{array}{c}11 \\
\text { Healthy } \\
\text { since } \\
\text { age } x\end{array}$ & $\begin{array}{c}12 \\
\text { In poor } \\
\text { health } \\
\text { state }\end{array}$ & $\begin{array}{c}13 \\
\text { Years } \\
\text { lived in } \\
\text { poor } \\
\text { health } \\
\text { state }\end{array}$ \\
\hline$x$ & ${ }_{n} M_{x}$ & $n q_{x}$ & $\mathrm{I}_{\mathrm{x}}$ & ${ }_{n} L_{x}$ & $\mathrm{~T}_{\mathrm{x}}$ & $e_{x}$ & $n \pi_{x}$ & $\left(1-{ }_{n} \pi_{x} / 100\right)^{\star} L x$ & $\mathrm{TH} x$ & $e_{x}^{\prime}$ & $e_{x}-e_{x}^{\prime}$ & $\%$ \\
\hline 20 & 0.00188 & 0.0094 & 100,000 & 497,656 & $5,433,619$ & 54.34 & 3.58 & 479,829 & $4,739,131$ & 47.39 & 6.94 & 12.8 \\
\hline 25 & 0.00216 & 0.0108 & 99,062 & 492,646 & $4,935,963$ & 49.83 & 3.90 & 473,417 & $4,259,302$ & 43.00 & 6.83 & 13.7 \\
\hline 30 & 0.00256 & 0.0127 & 97,996 & 486,867 & $4,443,316$ & 45.34 & 3.80 & 468,354 & $3,785,885$ & 38.63 & 6.71 & 14.8 \\
\hline 35 & 0.00318 & 0.0158 & 96,750 & 479,933 & $3,956,450$ & 40.89 & 6.79 & 447,324 & $3,317,531$ & 34.29 & 6.60 & 16.1 \\
\hline 40 & 0.00432 & 0.0214 & 95,223 & 471,029 & $3,476,517$ & 36.51 & 7.80 & 434,275 & $2,870,207$ & 30.14 & 6.37 & 17.4 \\
\hline 45 & 0.00602 & 0.0296 & 93,189 & 459,040 & $3,005,489$ & 32.25 & 10.98 & 408,644 & $2,435,932$ & 26.14 & 6.11 & 19.0 \\
\hline 50 & 0.00829 & 0.0406 & 90,427 & 442,961 & $2,546,448$ & 28.16 & 13.72 & 382,183 & $2,027,287$ & 22.42 & 5.74 & 20.4 \\
\hline 55 & 0.01193 & 0.0579 & 86,757 & 421,219 & $2,103,487$ & 24.25 & 15.85 & 354,476 & $1,645,104$ & 18.96 & 5.28 & 21.8 \\
\hline 60 & 0.01700 & 0.0816 & 81,730 & 391,988 & $1,682,268$ & 20.58 & 17.12 & 324,877 & $1,290,628$ & 15.79 & 4.79 & 23.3 \\
\hline 65 & 0.02450 & 0.1154 & 75,065 & 353,666 & $1,290,280$ & 17.19 & 21.05 & 279,210 & 965,751 & 12.87 & 4.32 & 25.2 \\
\hline 70 & 0.03660 & 0.1677 & 66,401 & 304,174 & $9,366,15$ & 14.11 & 20.26 & 242,544 & 686,541 & 10.34 & 3.77 & 26.7 \\
\hline 75 & 0.05437 & 0.2393 & 55,268 & 243,275 & 632,440 & 11.44 & 24.14 & 184,554 & 443,997 & 8.03 & 3.41 & 29.8 \\
\hline 80 & 0.10803 & 1.0000 & 42,042 & 389,165 & 389,165 & 9.26 & 33.33 & 259,443 & 259,443 & 6.17 & 3.09 & 33.3 \\
\hline
\end{tabular}




$$
{ }_{5} q_{x}=\frac{10 \mathrm{x}_{n} M_{n}}{2+5 \mathrm{x}_{n} M_{n}} .
$$

Note that in the last age group, at the open interval, every individual will die. The probability of death in this interval $\left({ }_{\infty} q_{80}\right)$ equals 1 .

Given these probabilities of death, the number of survivors reaching the initial age of the following age group can be calculated $\left(l_{x+5}\right)$. Thus: $l_{x+5}=l_{x} \mathrm{x}\left(1-{ }_{5} q_{x}\right) \quad$ (3).

It was assumed that the number of survivors reaching twenty years of age equals 100,000. According to Table 2, the number of survivors reaching 25 years of age $\left(l_{25}\right)$ is equal to 99,062 (column 4).

The next column in the life table shows the number of lived years between the ages $x$ and $x+5$. Every individual that survived the age of $x+5$ will fully live the period of five years. The ones who die before reaching the age of $x+5$ $\left(1_{x}-1_{x+5}\right)$ will live half the amplitude of the interval (2.5 years), assuming the deaths are uniformly distributed along the interval. Thus: ${ }_{5} L_{x}=$ $5 \times 1_{x+5}+2,5 \times\left(1_{x}-1_{x+5}\right)$. For the open interval,

$$
{ }_{\infty} L_{x}=\frac{l_{x}}{{ }_{\infty} M_{x}} .
$$

The survivors reaching twenty years of age will, added together, live 497,656 years in the subsequent five years (column 5).

In column 6 is presented the total number of years to be lived by the survivors in the age group $x$, until the group extinguishes itself. This is done by accumulating the lived years in each interval:

$$
T_{x}=\sum_{a=x}^{\infty}{ }_{n} L_{a}
$$

Survivors reaching the age of twenty will altogether live a total of 5,433,619 years. The life expectancy is calculated by dividing the numbers of years one expects to live starting from a certain age by the number of survivors to the referred age:

$$
e_{x}=\frac{T_{x}}{l_{x}}(6)
$$

According to the mortality rates used for the year 2003, at the age of twenty, one is expected to live an additional 54.34 years (column 7).

The proportion of individuals, of both sexes, that self-reated their health as poor ("bad" or "very bad") is presented in the eighth column. The prevalence increases monotonically with age except between the second and third age groups. The ninth column shows the healthy years lived in each age group by subtracting the total portion of years lived in an unhealthy state (column 8) from the total years lived (column 5). By cumulatively summing these values, the number of people-years that will be lived healthily from a determined age $x$ (column 10) is obtained. Of the $5,433,619$ years expected to be lived from the age of twenty, $4,739,131$ will be lived in a healthy state.

Similar to the traditional mortality table, the expectancy of healthy life $\left(e_{x}^{\prime}\right)$ is calculated by dividing the number of people-years lived in a healthy state from a certain age $x$ by the survivors of the referred age. As can be observed in column 11 of Table 2, at the age of twenty, one expects to live another 47.4 healthy years. Consequently, 6.9 years are lived in a poor state of health (column 12), corresponding to $12.8 \%$ of the life expectancy at that age (column 13).

The method of calculation presented in Table 2 was also used for the second and third estimates of healthy life expectancy. For the second estimate, the prevalence rate of individuals with a poor self-rated health is substituted for each age group by the proportion of individuals who reported having a long-term disease or disability which limits their daily activities. For the third estimate, the specific rate by age of being unhealthy is given by the average score of functional limitations estimated in the factor analysis.

The fourth methodology involved three situations (no disease or disability; with disease or disability but without limitation; with disease or disability and with resulting limitation) and weights to mark the severity of each situation according to the individual's age. To accomplish this estimate, a minor adaptation of the Sullivan method was made, as illustrated in Table 3.

To calculate healthy life expectancy with more than two health events, the population is classified in $s+1$ categories, including all individuals, from those with no health problem to those with the most severe cases. Accordingly, $P_{0}, P_{1}, \ldots ., P_{s}$ represents the proportions of the population in each category, and $w_{0}, w_{1}, \ldots . ., w_{s}$ represents the weight describing the severity of each state of health, measured on a scale from 0 (best health state) to 1 (worst health state). In this case, the specific rate by age of not being healthy ${ }_{5} \pi_{x}$ is given by the average of the scores weighted by the proportion of individuals in each category of each age group:

$$
{ }_{5} \pi_{x}=\sum_{a=0}^{s} w_{a} * P_{a} .
$$


Table 3

Healthy life expectancy based on factorial analysis (method 2). World Health Survey, Brazil, 2003.

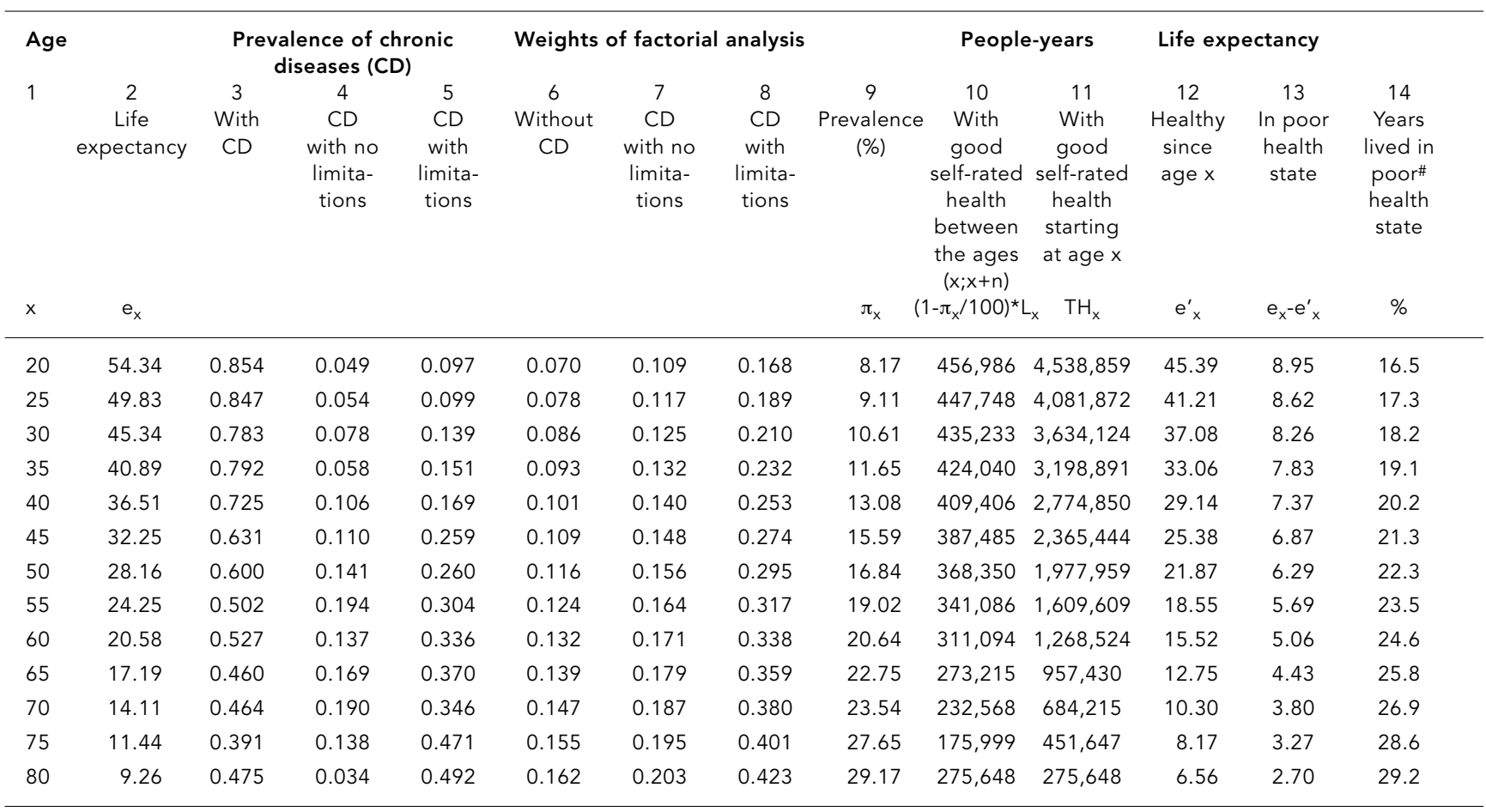

\# In this study disabilities are defined as a poor health state.

In Table 3, the functions of the mortality table were omitted except for life expectancy, shown in column 2 , since the calculations for the other columns were given in Table 2 . Columns 3, 4 and 5 show the proportions of individuals of both sexes in each category, adjusted using a multinomial model because they display great oscillation between ages. Columns 6, 7 and 8 show the weights calculated as an average of the scores of functional limitations (on a scale from 0 to 1 ) by category and age group. The weighted average $\left(\pi_{x}\right)$ is presented in column 9. In the first age group, the prevalence of poor states of health is equal to $0.0817(0.854 \mathrm{x}$ $0.070+0.049 \times 0.109+0.097 \times 0.168)$. The other functions are calculated according to the methods presented above.

\section{Results}

Table 4 displays the total life expectancy and the total healthy life expectancy for the ages of twenty and sixty years, according to sex. The number of unhealthy years lived is also shown, as well as its relative proportion of the total life expectancy.
In reference only to the mortality component, females at the age of twenty expect, on average, to live approximately seven years more than males ( 57.8 years versus 51.0 years). At the age of sixty the difference by sex is, on average, three years in favor of females. Concerning the expectancy of a healthy life, given that females live more years in poor health or with limitations, the difference in healthy life expectancy between males and females is smaller both at the age of twenty and sixty (Table 4).

Comparing all four methodologies indicates that the estimate with greatest loss in healthy years is the one based only on the occurrence of a long-term disease or disability that causes limitations, not considering the resulting degree of hardship in performing daily activities and the severity of functional limitations (method 2). According to the estimate, at the age of sixty, it is expected that males lose, on average, $35.0 \%$ of the years yet to be lived with limitations that result from long-term diseases. This average is $44.0 \%$ for females.

The other methodologies employed show estimates closer to each other. The measurement of unhealthiness through poor self-rated health is the one that presents the smallest rela- 
Life expectancy and healthy life expectancy at the age of twenty and sixty, by gender and selected methods. World Health Survey, 2003.

\begin{tabular}{|c|c|c|c|c|}
\hline Methods & $\begin{array}{c}\text { Life } \\
\text { expectancy } \\
\left(e_{x}\right)\end{array}$ & $\begin{array}{c}\text { Healthy life } \\
\text { expectancy } \\
\left(e_{x}^{\prime}\right)\end{array}$ & $\begin{array}{l}\text { Years lived in } \\
\text { poor health } \\
\text { state }\end{array}$ & $\begin{array}{l}\text { Years lived in } \\
\text { poor health } \\
\text { state }(\%)\end{array}$ \\
\hline \multicolumn{5}{|l|}{ Life expectancy at 20 years of age } \\
\hline Both genders & 54.34 & & & \\
\hline M1 (poor self-rated health) & & 47.39 & 6.94 & 12.8 \\
\hline M2 (diseases with limitation) & & 40.81 & 13.52 & 24.9 \\
\hline M3 (disabilities) & & 45.29 & 9.05 & 16.7 \\
\hline M4 (presence of disease/disability) & & 45.39 & 8.95 & 16.5 \\
\hline Females & 57.75 & & & \\
\hline M1 (poor self-rated health) & & 49.13 & 8.62 & 14.9 \\
\hline M2 (diseases with limitation) & & 41.56 & 16.18 & 28.0 \\
\hline M3 (disabilities) & & 46.46 & 11.29 & 19.5 \\
\hline M4 (presence of disease/disability) & & 47.72 & 10.03 & 17.4 \\
\hline Males & 50.98 & & & \\
\hline M1 (poor self-rated health) & & 45.74 & 5.24 & 10.3 \\
\hline M2 (diseases with limitation) & & 40.12 & 10.87 & 21.3 \\
\hline M3 (disabilities) & & 44.22 & 6.76 & 13.3 \\
\hline M4 (presence of disease/disability) & & 43.06 & 7.92 & 15.5 \\
\hline \multicolumn{5}{|l|}{ Life expectancy at 60 years of age } \\
\hline Both genders & 20.58 & & & \\
\hline M1 (poor self-rated health) & & 15.79 & 4.79 & 23.3 \\
\hline M2 (diseases with limitation) & & 12.34 & 8.25 & 40.1 \\
\hline M3 (disabilities) & & 15.38 & 5.21 & 25.3 \\
\hline M4 (presence of disease/disability) & & 15.47 & 5.11 & 24.9 \\
\hline Females & 22.01 & & & \\
\hline M1 (poor self-rated health) & & 16.39 & 5.63 & 25.6 \\
\hline M2 (diseases with limitation) & & 12.30 & 9.72 & 44.1 \\
\hline M3 (disabilities) & & 15.75 & 6.26 & 28.4 \\
\hline M4 (presence of disease/disability) & & 16.33 & 5.69 & 25.8 \\
\hline Males & 19.02 & & & \\
\hline M1 (poor self-rated health) & & 15.04 & 3.98 & 20.9 \\
\hline M2 (diseases with limitation) & & 12.28 & 6.75 & 35.5 \\
\hline M3 (disabilities) & & 14.86 & 4.16 & 21.9 \\
\hline M4 (presence of disease/disability) & & 14.49 & 4.53 & 23.8 \\
\hline
\end{tabular}

tive loss in terms of healthy years of life, independent of gender. At twenty years of age males expect to lose around $10.3 \%$ of life expectancy to poor health and females, $14.9 \%$. At sixty years of age this proportion reaches $20.9 \%$ among males and $25.6 \%$ among females.

The tendency for the proportion of individuals in an unhealthy state to increase with age is found in all four estimates. However, the greatest variation in the relative loss of healthy years, between twenty and sixty years of age, is found for the estimate based on self-rated health, while the smallest corresponds to the methodology based on the severity scale of functional limitations.

Figure 1 shows life expectancy and the estimates of healthy life expectancy, by sex, according to method employed. Results indicate that for all ages, independent of the method employed, life expectancy is greater among females. However, females lose, relatively, more healthy years than males. Among the defining measures of being healthy, the greatest loss in years of healthy life results prominently in every 
Figure 1

Life expectancy and healthy life expectancy, according to sex, age, and method. World Health Survey, Brazil, 2003.

Figure 1a

Both sexes

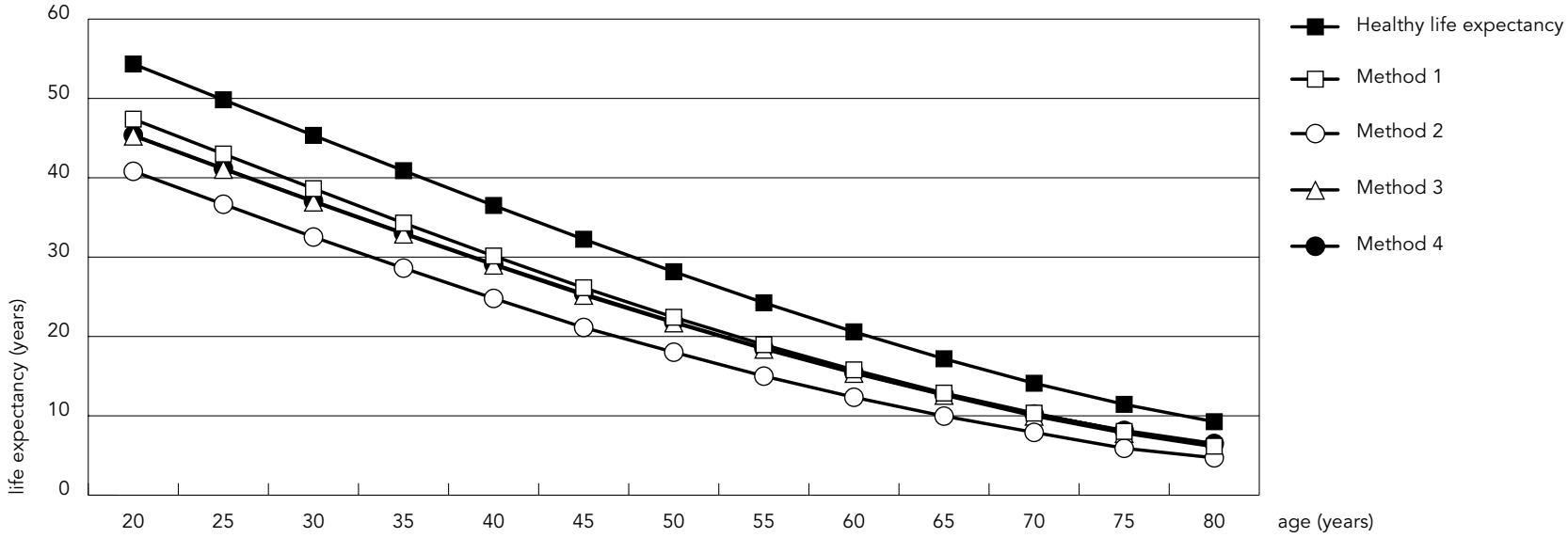

Figure $1 b$

Men

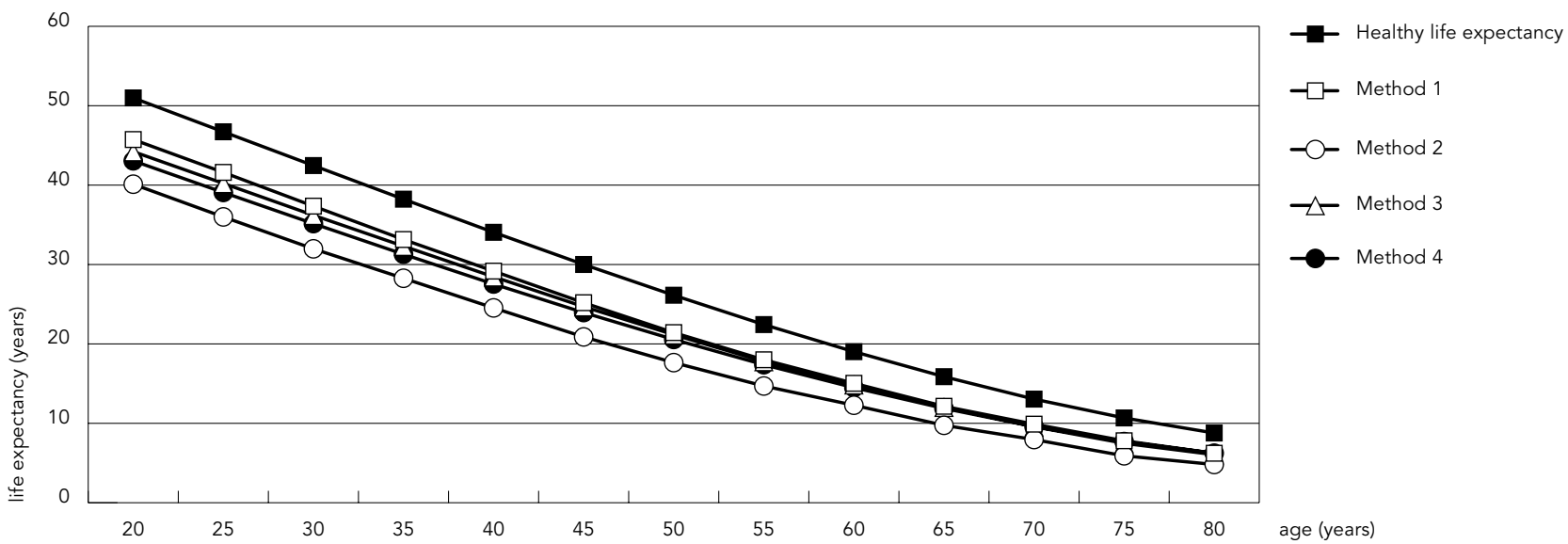

(continues) 


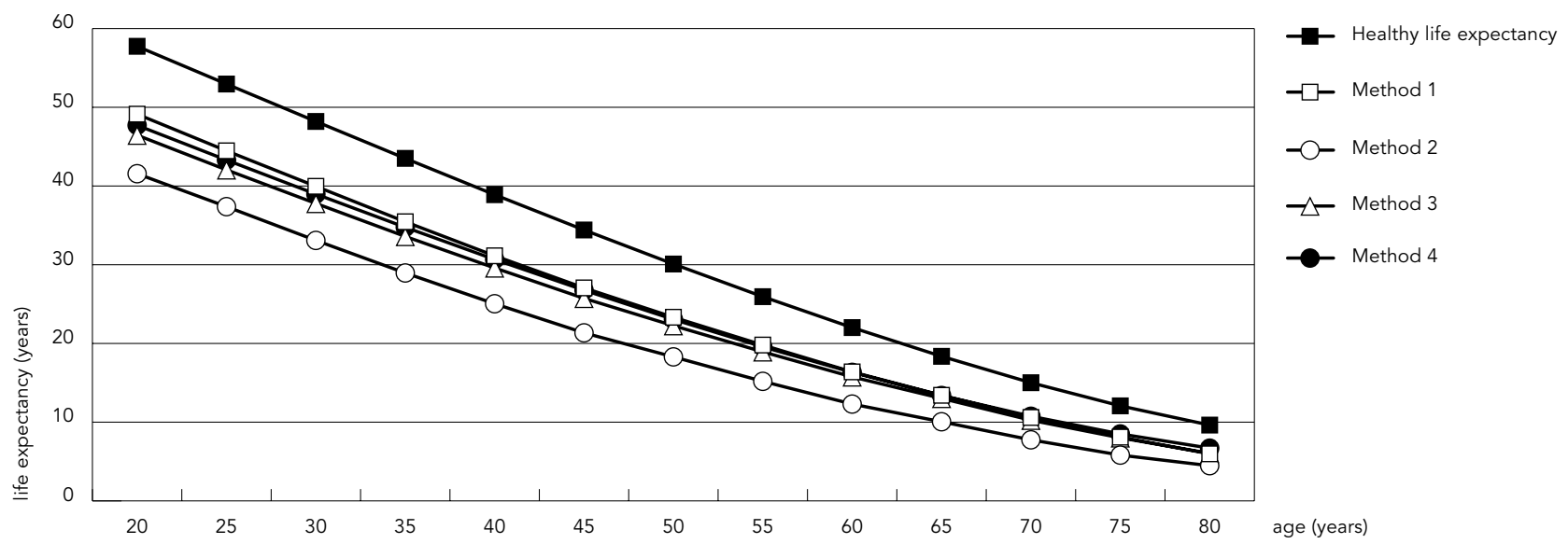

age group from the presence of a long-term disease or disability which limits daily functions. The other three measures produce values that differ little from each other.

\section{Final comments}

Since its creation, the WHO defined health as a complete state of physical, mental, and social well-being. This definition transcends the absence of death, disease, and disability, and incorporates concepts relative to well-being and to quality of life. In such context, the concept of healthy life expectancy or life expectancy free of disability emerges; a generic term which characterizes a population's indicators that estimate the average timeframe (in years) a person may expect to live in a healthy state.

Ever since the 1980s, a growing number of studies employ the Sullivan method 11,15 due to its mathematical simplicity, the availability of required data, and the ease of interpreting its results. This indicator has also been adopted for monitoring health in European countries, Project REVES (Réseau Espérance de Vie en Santé) 23,24, and by the United States' governmental health plan Healthy People 2010 25. This method has also been employed to evaluate disparity in health by means of estimates of healthy life years according to socioeconomic indicators such as income and schooling 26,27.

There exists a certain consensus as to the potential of healthy life expectancy as a measure to monitor and evaluate the action of health programs and politics 2 . Differences exist in relation to the selection of measurement for indicating a healthy life. Some authors prefer measurements of relatively objective states, such as disability and diagnosed chronic diseases 28 , arguing that interference by the cultural context should be avoided 29,30. On the other hand, there are authors who consider it important to incorporate the subjective dimension, such as self-rated health, because they consider it a strong factor in predicting mortality, well-being, and the use of health services 26,31 .

The inclusion of various measures in the present study raises an important methodological question of how to measure healthiness 32 , whether it be with simple or combined indicators, or by incorporating or not the severity of each situation.

In this study, the first two measures employed did not consider the seriousness of each situation but only the occurrence of a negative event. Authors such as Crimmins 32 favor the use of various dichotomous health measures, since they provide more specific information than those based on measures involving a continuum in severity, and are thus more efficient for implementing and monitoring health politics.

Some scholars of healthy life expectancy, like Robine \& Jagger 31, Mathers et al. 33 and Murray \& Frenk 34 , have emphasized the need to incorporate the degree of severity to each event. These authors point out that when only binary indicators are used, such as the individ- 
ual's personal perception of poor health or the inception of a chronic disease, the occurrence of these events is what determines the greatest loss in years of healthy life. In fact, the estimate based only on the presence of a long-term illness that limits daily activities was what caused the greatest relative loss in healthy years for both sexes at all ages.

The third methodology employed in this study to estimate the healthy life expectancy attempted to establish a continuous degree of severity based on scores of functional limitations constructed with an analysis that reduced the different dimensions of the interviewee's state of health to a single component. An extension of the Sullivan method was also proposed which incorporates three situations derived from the presence, or lack thereof, of a long-term illness combined with the occurrence of limitations to daily activities, in addition to the degree of severity for each one of them, based on the functional limitation scores. However, the two healthy life estimates that involved adjustment by severity of limitations produce very similar results to the estimates based on self-rated health, especially at an advanced ages.

The findings in this study highlight the consistency in the WHS' results. It is observed, for all measures employed, that the proportion of healthy life years lost significantly increases with age and that, even though females have a longer life expectancy than males, they live, relatively, less years in good health. Similar to a study developed in Belgium 35, healthy life ex- pectancy was greatest when estimated using poor self-rated health than when calculated from the presence of disabilities and illnesses.

What is most important to note is that, despite from the index's sensitivity, all measures follow the same pattern, varying only in degree. It is observed that the differences between the various estimates of healthy life expectancy was greatest between younger females but was only relevant when the estimate was based on the presence of a disease or disability that limits daily functions.

Contrary to the multistate life table method, which employs longitudinal data, the Sullivan method has been criticized for not taking into consideration reversible health states 36,37 . However, Mathers \& Robine 38 , employing various simulation models and possible scenarios, conclude that unless the situation is one of sudden and radical change in the transition rate of the state of health, which is uncommon, the Sullivan method provides strong estimates for monitoring trends in healthy life expectancy.

This article attempts to introduce the Sullivan method for calculating healthy life expectancy to national Brazilian literature, in order to establish a debate around the various indicators of state of health, based not only on mortality information, but also considering the effects of morbidity. Whereas death is a single event, the loss of healthy life is hard to quantify. Hopefully, the different proposals for measuring well-being, combined with to the simplicity and strength of the Sullivan method, may help stimulate this emergent debate in Brazil.

\section{Resumo}

Este estudo tem como objetivos apresentar a técnica proposta por Sullivan e estimar a expectativa de vida saudável, utilizando diferentes formas de mensurar o estado de saúde, com base em informações provenientes da Pesquisa Mundial de Saúde realizada no Brasil em 2003. Pela combinação de informação de mortalidade e morbidade num único indicador, simplicidade do cálculo e fácil interpretação dos resultados, $o$ método de Sullivan é atualmente o mais usado para estimar expectativa de vida saudável. Os resultados mostraram que a maior perda de anos saudáveis é obtida quando há ocorrência de doença de longa duração ou incapacidade que limitam as atividades habituais, independentemente do grau de dificuldade em realizar as atividades cotidianas e a severidade das $l i$ - mitações funcionais. As duas estimativas de expectativa de vida saudável ajustadas pela severidade das $l i$ mitações mostraram resultados muito similares àquelas estimadas com base na percepção do estado de saúde, especialmente para as idades avançadas. $\mathrm{Ob}$ serva-se, para todas as medidas utilizadas, que a proporção de anos perdidos de vida saudável aumenta significativamente com a idade e que, embora as mulheres tenham uma expectativa de vida maior que a dos homens, elas vivem proporcionalmente menos anos com boa saúde.

Doenças Crônicas; Nível de Saúde; Esperança de Vida; Anos de Vida Perdidos 


\section{Contributors}

All the authors participated in drafting, analysis and review of the paper.

\section{Acknowledgments}

The present work had financial support from the Conselho Nacional de Desenvolvimento Científico e Tecnológico (CNPq; National Counsel for Scientific Development and Technology) and from the Departamento de Ciência e Tecnologia (DECIT; Department of Science and Technology), Ministério da Saúde (Ministry of Health).

\section{References}

1. Gold MR, Stevenson D, Fryback DG. HALYS and QALYS and DALYS, oh my: similarities and differences in summary measures of population health. Annu Rev Public Health 2002; 23:115-34.

2. Molla MT, Madans JH, Wagener DK, Crimmins EM. Summary measures of population health: Report of findings on methodologic and data issues. Hyattsville: National Center for Health Statistics; 2003. (Healthy People 2010).

3. Comisión Económica para América Latina y el Caribe/Centro Latinoamericano y Caribeño de Demografia. América Latina y el Caribe: estimaciones y proyecciones de población. 1950-2050. Santiago de Chile: Comisión Económica para América Latina y el Caribe, Naciones Unidas; 2004. (Boletín Demográfico 73).

4. Field JF, Gold GM, editors. Summarizing population health: directions for the development and application of population metrics. Washington DC: National Academies Press; 1998.

5. Rogers A, Rogers RG, Belanger A. Longer life but worse health? Measurement and dynamics. Gerontologist 1990; 30:640-9.

6. Verbrugge LM. Longer life but worsening health? Trends in health and mortality of middle-aged and older persons. Milbank Mem Fund Q Health Soc 1984; 62:475-519.

7. Olshansky SJ, Rudberg MA, Carnes BA, Cassel CK, Brody JA. Trading off longer life for worsening health: the expansion of morbidity hypothesis. J Aging Health 1991; 3:194-216.

8. Guzmán JM. Envejecimiento y desarrollo en América Latina y el Caribe. Santiago de Chile: Comisión Económica para América Latina y el Caribe/Centro Latinoamericano y Caribeño de Demografia; 2002. (Población y Desarrollo 28).

9. Triantafillou J, Mestheneos E, Levett J, Petsetakis E. The health of older people in the European Union: current state and future trends. http:// www.sextant.gr/HOEreport/HOEreport.htm (accessed on 14/Oct/2005).

10. Gruenberg EM. The failures of success. Milbank Mem Fund Q Health Soc 1977; 55:3-24.

11. Robine JM, Ritchie K. Healthy life expectancy: evaluation of global indicator of change in population health. BMJ 1991; 302:457-60.

12. Kenneth G, Manton KCL. Active life expectancy estimates for the U.S. elderly population: a multidimensional continuous-mixture model of functional change applied to completed cohorts, 19821996. Demography 2000; 37:253-66.
13. Sanders BS. Measuring community health levels. Am J Public Health Nations Health 1964; 54:1063-70.

14. Sullivan DF. A single index of mortality and morbidity. HSMHA Health Rep 1971; 86:347-54.

15. Mathers CD, Sadana R, Salomon JA, Murray CJL, Lopez AD. Healthy life expectancy in 191 countries, 1999. Lancet 2001; 357:1685-91.

16. Mutafova M, van de Water HP, Perenboom RJ, Boshuizen HC, Maleshkov C. Health expectancy calculations: a novel approach to studying population health in Bulgaria. Bull World Health Organ 1997; 75:147-53.

17. Camargos MCS, Perpétuo IHO, Machado CJ. Life expectancy with functional disability in elderly persons in São Paulo, Brazil. Rev Panam Salud Pública 2005; 17:379-86.

18. Vasconcellos MTL, Silva PLN, Szwarcwald CL. Sampling design for the World Health Survey in Brazil. Cad Saúde Pública 2005; 21 Suppl:S89-99.

19. Kaplan RM, Erickson P. Gender differences in quality-adjusted survival using a Health-Utilities Index. Am J Prev Med 2000;18:77-82.

20. Arber S, Cooper H. Gender differences in health in later life: the new paradox? Soc Sci Med 1999; 48:61-76.

21. Jagger C. Health expectancy calculation by the Sullivan method: a practical guide. Leicester: Euro-REVES/University of Leicester; 1997.

22. World Health Organization. International classification of functioning, disability and health: ICF. Geneva: World Health Organization; 2001.

23. Mathers CD, Robine J. Health expectancy indicators: a review of the work of REVES to date. In: Robine JM, Mathers CD, Bone MR, Romieu I, editors. Calculation of health expectancies, harmonization, consensus achieved and future perspectives. France: John Libbey Eurotext/Les Editions INSERM; 1993. p. 1-21.

24. Robine JM, Jagger C, Van Oyen H. The EURO-REVES approach: a vision for Europe. Geneva: Statistical Office of the European Communities, World Health Organization; 2004. (Report n. 16).

25. Mathers CD, Iburg KM, Salomon JA, Tandon A, Chatterji S, Ustun B, et al. Global patterns of healthy life expectancy in the year 2002. BMC Public Health 2004; 4:66.

26. Bossuyt N, Gadeyne S, Deboosere P, Van Oyen H. Socio-economic inequalities in health expectancy in Belgium. Public Health 2004; 118:3-10.

27. Valkonen T, Sihvonen AP, Lahelma E. Health expectancy by level of education in Finland. Soc Sci Med 1997; 44:801-8. 
28. Bone MR, Bebbington AC, Nicolaas G. Policy applications of health expectancy. J Aging Health 1998; 10:136-53.

29. Mathers CD. Health expectancies: an overview and critical appraisal. In: Murray CJL, Salomon JA, Mathers CD, Lopez AD, editors. Summary measures of population health: concepts, ethics, measurement and applications. Geneva: World Health Organization; 2002. p. 177-204.

30. Nord E. A review of synthetic health indicators. Oslo: National Institute of Public Health; 1997.

31. Robine JM, Jagger C. Creating a coherent set of indicators to monitor health across Europe: the Euro-REVES 2 project. Eur J Public Health 2003; 13:6-14.

32. Crimmins E. Health expectancies: what can we expect from summary indicators of population health? In: Murray CJL, Salomon JA, Mathers CD, Lopez AD, editors. Summary measures of population health: concepts, ethics, measurement and applications. Geneva: World Health Organization; 2002. p. 213-21.

33. Mathers CD, Murray CJ, Ezzati M, Gakidou E, Salomon JA, Stein C. Population health metrics: crucial inputs to the development of evidence for health policy. Popul Health Metr 2003; 1:6.
34. Murray C, Frenk J. Summary measures of population health in the context of the WHO framework for health system performance assessment. Murray CJL, Salomon JA, Mathers CD, Lopez AD, editors. Summary measures of population health: concepts, ethics, measurement and applications. Geneva: World Health Organization; 2002. p. 1-12.

35. Van Oyen H, Bossuyt N, Deboosere P, Gadeyne S, Tafforeau J. Differences in health expectancy indicators in Belgium by region. Arch Public Health 2002; 60:341-62.

36. Brouard N, Robine JM. A method for calculation of health expectancy applied to longitudinal surveys of the elderly in France. In: Robine JM, Blanchet M, Dowd JE, editors. Health expectancy. London: Institut National de la Santé et de la Recherche Médicale; 1992. p. 87-8.

37. Bebbington AC. Expectation of life without disability measured from the OPCS disability surveys. In Robine JM, Blanchet M, Dowd JE, editors. Health expectancy. London: Institut National de la Santé et de la Recherche Médicale; 1992. p 23-34.

38. Mathers CD, Robine JM. How good is Sullivan's method for monitoring changes in population health expectancies? J Epidemiol Community Health 1997; 51:80-6.

Submitted on $04 / \mathrm{May} / 2005$

Final version resubmitted on 16/Sep/2005

Approved on 26/Sep/2005 